\title{
ANALYSIS OF THE SPATIAL DISTRIBUTION OF THE DROUGHT IN THE LIM VALLEY AND ON THE UPPER COURSE OF THE RIVER IBAR IN MONTENEGRO
}

\author{
Eldin Brđanin*, Marko Sedlak ${ }^{1 *}$ \\ *University of Belgrade - Faculty of Geography, Belgrade
}

\begin{abstract}
This paper analyzed the spatial distribution of drought at meteorological stations on the Lim valley (Plav, Andrijevica, Berane and Bijelo Polje) and on the upper course of the river Ibar (Rožaje). The goal of this research is to point out the modern climatic characteristics in relation to the current state of aridization, which is a limiting factor for economy of the population in many areas throughout the world. The method used for such purposes is the De Marton drought index. Results of the research indicated a decrease in the annual drought index through the Lim valley, with the highest values for Plav (IDM=61,9), and the lowest for the lowest downstream station Bijelo Polje (IDM=41,3). The values of this climate index indicate the conditions of very humid (Berane, Bijelo Polje and Rožaje) and extremely humid climates (Plav and Andrijevica), with huge drainage and forest vegetation. By applying the De Marton index on a seasonal and monthly level, the highest values of this indicator were established in the winter season.
\end{abstract}

Keywords: De Marton drought index, seasonal drought index, monthly drought index, interpolation, aridization.

1 Corresponding author: M.Sedlak, phd student, University of Belgrade-Faculty of Geography, Belgrade; Studentski trg III/3, Belgrade;e-mail: maresedlak1@gmail.com 


\section{Introduction}

During the last decade, issues related to climate change are being researched by numerous scientific studies (Bačević et al., 2017; Gavrilov et al., 2019). Temperature and rainfall are the most important climate elements. Popović, Radulović and Jovanović (2020) established that the average temperature of the planet Earth is around $15^{\circ} \mathrm{C}$. The merit for such result belongs to the greenhouse effect. Number of international agreements exists in the field of environment that contain different types of goals and principles relevant to the field of climate change. Atmospheric protection includes: the Convention on Long-range Transboundary Air Pollution (1979) with its 8 protocols and 4 amendments, the Vienna Convention for the Protection of the Ozone Layer (1985) and the Montreal Protocol on Substances that Deplete the Ozone Layer with its 4 amendments, UNFCCC ( 1992) with the Kyoto Protocol (1997), the Amendment to Annex B of the Kyoto Protocol (2006) and the Doha Protocol (2012), which is yet to be enforces (Todić, 2016).

Numerous studies have concluded that the process of aridization is included at the regional and global level (Ahmed et al., 2019). Drought related research are intensified in scientific circles for the last two decades (Tadić, Dadić, \& Bosak, 2015). Drought is a natural disaster which characterized by the length of the dry period that is significantly above normal. In other words, the deficit of precipitation is significantly below normal (Dragićević and Filipović, 2009). Unlike natural disasters in which the effect is manifested immediately after its occurrence (floods, eruptions, earthquakes), droughts are a natural phenomenon that is characterized by slow development and can last a long time. Its influence is manifested for months and even years after its appearance (Dragićević and Filipović, 2009; Spinoni, Naumann, \& Vogt, 2017). Aridity is a critical factor in determining the evolution of natural vegetation, taking into account the water stress that can occur with the reduction of vegetation cover (Kosmas et al., 1999).

The effects of drought on the environment can be direct (biophysical: changes in site conditions, decrease of water level) and indirect (such as reduced income from agricultural production, increasing food prices). The increase in droughts can negatively affect water resources, agricultural production and activities that rely on surface water and groundwater (Dragicevic and Filipovic, 2009; Gebremedhin, Kahsay \& Fanta, 2018; Paltineanu et al., 2007). The impact of the drought on the environment is reflected in land degradation, which affects the reduction of natural resources areas (Rajic, 2014). Monitoring the situation of drought is especially important 
Analysis of the spatial distribution of the drought in

the Lim valley and on the upper course of the river Ibar in Montenegro

in areas where agriculture is the dominant activity of the economy, as well as for management of degraded land and desertification processes (BarzaniMarani et al., 2017;Pelliconi, Caloiero, \& Guagliardi, 2019).

Numerous experts study the intensity and spatial distribution of drought in the world: in Ethiopia, Iran, Pakistan, India (Ahmed et al., 2019; Dabbaghi and Manjari, 2017; Gebremedhin, Kahsay \& Fanta, 2018; Piri et al., 2017;Rakhecha \& Dhar, 1975). The differences are attending due to the geographical position, relief (direction of the mountains) and distance from the sea. In Europe, drought is mostly affecting the southern and southeastern part of the continent (Tadić, Dadić \& Bosak, 2015). De Marton droughtindex method used for analysis of drought on the Danube Delta between 1965 and 2005 revealed values below IDM= 20 for the most part (Lungu, Panaitescu \& Plesoianu, 2012). In Greece, between 1965 and 1995, the differences in the value of the De Marton drought index were found between Larissa $(\mathrm{IDM}=16,28)$ in the east and Ioannina in the west (IDM=43,01), due to the meridian extension of Mount Pind (Balzas, 2007). In the period from 19651999, the growth of this index from Pristina and East (IDM=30) to the south (up to IDM=45) was established on the territory of Kosovo and Metohija, which is influenced by the growth of precipitation and high mountains on the edge (Bačević et al., 2017). In the period from 1981-2010, the annual value of the De Marton index of IDM=29,6 was established on the territory of the Leskovac valley (Milentijević et al., 2018).

\section{Research area}

Data were analyzed at meteorological stations in the valley of Lim (Plav, Andrijevica, Berane and Bijelo Polje) including a meteorological station Rožaje, on Ibar valley in the eastern part of Montenegro. The research area includes the mountain part of Montenegro - Montenegrin mountains and surfaces (Marković, 1966). Mountains have a large impact on the climate, because the changes of altitude change the climate elements in the form of reducing temperature and increasing precipitation (Rakićević, 1971; Vujević, 1948).

Rozaje is on the eastern part of Montenegro in the upper Ibar. It borders the municipality of Berane and the municipality of Petnjica, while the rest of its border is also the state border of Montenegro between Serbia (Radojičić, 2015). Municipality Rožaje, by geographical location and altitude, belongs to moderate-continental zone where predominates climate with cold winters and cool summers. The average number of days in a year with a temperature 
below $0^{\circ} \mathrm{C}$ is 166 , and with a temperature above $30^{\circ} \mathrm{C}$ is 4 days (Radojičić, 2008). Insolation is about 1500 hours a year (around 4 hours a day), which is a significant value for mountainous areas (Ministry of Agriculture and Rural Development of Montenegro, 2020).

The municipality of Plav is located in the southeastern part of Montenegro, near Lake Plav. It borders the municipalities of Andrijevica and Berane. A significant feature in the relief is Prokletije. At the time of the last glacial (Würm), the ice on Prokletije covered an area of $250 \mathrm{~km} 2$ (Cvijić, 1921). The climate of the Plav-Gusinje region is mountain-valley, and at altitudes above $1300 \mathrm{~m}$ it is distinctly mountainous (Radojičić, 2005). Because of its natural characteristics, Plav represents a mountainous place and climatic spa (Marković, 1966).

The meteorological station in the municipality of Andrijevica is located at the altitude of $772 \mathrm{~m}$. Between sea and municipality, there is around $88 \mathrm{~km}$ of air line. It is located in the valley extension of the river Lim. The municipality is developed on fluvio-glacijal terrace, on the left side of the river Lim, between Zlorečica and Krasta. It is located at the crossroads of roads to Berane, Podgorica, Plav and Peja (Bakić, 2005; Marković, 1966).

Berane, with the meteorological station at the altitude of $690 \mathrm{~m}$, is the center surrounded by Andrijevica, Petnjica and Plav. Municipality has been developed on northern-east part of Berane valley. Berane valley has continental climate. Because of the differences in climatic elements, climatic regionalization in the Lim valley has been done on Berane variety (higher average and maximum temperatures) and on Plav-Gusinje climate variety region (Joksimović, 2016).

Municipality of Bijelo Polje is the fifth largest municipality in Montenegro by area and third by population. It borders Berane on south-east, on west it borders Mojkovac, and on the north-west it borders Pljevlja. The climate of Bijelo Polje is moderate continental (Radojičić, 2002).

Table 1. Meteorological stations

\begin{tabular}{|l|l|l|l|}
\hline Meteorological stations & Latitude $(\varphi)$ & Longitude $(\lambda)$ & Altitude $(\mathrm{m})$ \\
\hline Rožaje & $42^{\circ} 51^{\prime}$ & $20^{\circ} 10^{\prime}$ & $1007 \mathrm{~m}$ \\
\hline Plav & $42^{\circ} 36^{\prime}$ & $19^{\circ} 56^{\prime}$ & $910 \mathrm{~m}$ \\
\hline Andrijevica & $42^{\circ} 44^{\prime}$ & $19^{\circ} 47^{\prime}$ & $772 \mathrm{~m}$ \\
\hline Berane & $42^{\circ} 50^{\prime}$ & $19^{\circ} 52^{\prime}$ & $690 \mathrm{~m}$ \\
\hline Bijelo Polje & $43^{\circ} 02^{\prime}$ & $19^{\circ} 45^{\prime}$ & $606 \mathrm{~m}$ \\
\hline
\end{tabular}

Source: Department of Hydrometeorology and Seismology of Montenegro, 2008-2018 
Analysis of the spatial distribution of the drought in the Lim valley and on the upper course of the river Ibar in Montenegro

\section{Data and research methodology}

The research is limited to the period between 2009 and 2018. Analysis of climate parameters has been conducted at the period of one decade because of the lack of data for longer period of time. Data were taken for each year individually from the website of the Institute of Hydrometeorology of Montenegro. In order to obtain values of the annual, seasonal and monthly De Marthon drought index, we needed to take the monthly and annual values for the temperature and precipitation. The initial hypothesis of this research is that the process of aridization is still not expressed in the mountain areas.

While forming the database, data for specific montly values of temperature and precipitation were missing. Such case was with the meteorological stations in Rozaje, Bijelo Polje and Andrijevica, while data were complete at the stations in Plav, Berane and Kolasin. Lack of some values were resolved using the interpolation procedure.

With the help of available data on other stations, the prediction of unknown geographical data on stations for which they are missing is performed (Gebremedhin, Kahsay \& Fanta, 2018). Interpolation of mean monthly and mean annual temperature values was performed by applying the method of differentiation with the help of the two nearest stations for the same length of the data series. The missing monthly temperature values from Rozaje and Andrijevica were interpolated with the help of the meteorological stations at Berane and Plav. Monthly temperature values at Bijelo Polje were interpolated with the help of the temperature values at the stations at Berane and Kolasin $\left(\varphi=42^{\circ} 50^{\prime}\right.$ and $\lambda=19^{\circ} 31^{\prime}$, altitude of $\left.944 \mathrm{~m}\right)$. The method of this differentiation was conducted according to the following pattern (Ducić and Anđelković, 2009):

$$
T a m=\frac{[(\mathrm{Tbm}+\mathrm{Dab})+(\mathrm{Tcm}+\mathrm{Dac})]}{2}
$$

Tbm and Tcm represents mean montly values of temperature on the stations that are being used to compare temperature values, for the month that is lacking values. Dab and Dac expresses mean differences between temperatures from the stations for which the interpolation is performed with the stations on which the comparison is made.

Interpolation of monthly and annual amounts of precipitation was performed by applying the quotient method, because this method is suitable for interpolation of those climatic elements whose values are expressed 
in sum. Interpolation of monthly precipitation amounts at meteorological stations Bijelo Polje, Rožaje and Andrijevica was performed with the same stations, as in the case of temperature interpolation. The results were obtained according to the following formula (Ducić and Anđelković, 2009):

$$
\text { Pam }=\frac{[(\mathrm{Pbm} * \mathrm{Qab})+(\mathrm{Pcm} * \mathrm{Qac})]}{2}
$$

$\mathrm{Pbm}$ and Pcm represent values of monthly sum of precipitation at the stations with which the interpolation is performed, with the month that is lacking data. Qab and Qac represents quotients between the station for which the data is lacking with the similar stations on which the data for specific month exists.

Climate indexes represents significant indicators of climate changes (Gebremedhin, Kahsay, \& Fanta, 2018). Drought indexes are climate indexes that are being used for following and prediction of the droughts (Piri et al., 2017). Drought indexes are most simplified tool for analyzing this phenomenon (Zemunac, Rajić \& Bezdan, 2018). It is really hard to find universal index, due to differences in the drought definition itself (Rajić and Zemunac, 2017). For the better part, they are based on hydrological parameters, such as flow and water level, and meteorological parameters: precipitation and air temperature (Tadić, Dadić\& Bosak, 2018). Drought indexes represents numerical indicators of the degree of dryness of the climate at particular location and provide base for classification of climate types, while depending on the availability of the water resources (Pellicone, Caloiero \& Guagliardi, 2019). There are numerous indexes that are being used to analize drought of specific area: De Marton's drought index, Gracanin's rain factor, Johanson's continental index, Seljanin's hydrothermal coefficient, Lang's rain factor, standardized climate water balance index, Palmer's index of drought, Palfaiev's index of drought, UNESCO drought index (Balzas, 2007; Barzani-Marani et al., 2017; Gebremedhin, Kahsay, \& Fanta, 2018; Lungu, Panaitescu \& Plesoianu, 2012;Milentijević et al., 2018; Paltineanu et al., 2007; Rajić, 2017;Tadić, Dadić\& Bosak, 2015; Zemunac, Rajić \&Bezdan, 2018).

De Marton's drought index represents significant climate index which performs a detailed characterization of the climate in certain area (Ducić and Anđelković, 2009). This index can be used for calculation of the different periods of time, such as months, seasons and years (Gavrilov et al., 2019). The increase of value on the De Marton's drought index suggests that climate is more humid, while the decrease of the value indicates an aridization of the 
Analysis of the spatial distribution of the drought in the Lim valley and on the upper course of the river Ibar in Montenegro

climate of the studied region (Dabbaghi and Manjari, 2017; Lungu, Panaitescu \& Plesoianu, 2012). Annual values of De Marton's index were calculated in order to represent characteristics of humidity, while the seasonal and monthly values were calculated to analyze the variability of such parameter during the year (Milentijević et al., 2018). De Marton's index is considered as one of the conventional methods in the climate classifications and it is often used in climate research projects, especially in development of water-gate and in agricultural area (Piri et al., 2017).

De Marton's drought index determines the characteristics of the climate, but also the characteristics of landscape, such as drainage and runoff (table 2). E. De Marton found out that the value of drought index IDM=20 represents the limit of dryness and that this number might be handy for determining dry months during the year (Dukić, 1976). Index values are an indication of the type of drainage territory, so it can be areic, endoreic, exorheic and an area of abundant exorheic drainage. Desert and semi-desert areas correspond to index values below IDM $<10$. Areas with a De Marton index between 10 and 30 are steppe and wooded steppe areas, while areas with an index over 30 are forest areas.

Table 2. Characteristics of the area depending of the value of De Marton's drought index

\begin{tabular}{|l|l|l|l|l|}
\hline Index values & Climate types & Index values & Drainage & Area \\
\hline IDM $<10$ & Dry & IDM $<5$ & Areic areas & Desert \\
\hline $10 \leq \mathrm{IDM}<20$ & Mildly dry & $5<\mathrm{IDM}<10$ & Endorheic area & Border desert \\
\hline $20 \leq \mathrm{IDM}<24$ & Mediterranean & $10<\mathrm{IDM}<20$ & $\begin{array}{l}\text { Exo/endorheic } \\
\text { area }\end{array}$ & Steppes \\
\hline $24 \leq \mathrm{IDM}<28$ & Mildly wet & $20<\mathrm{IDM}<30$ & Exorheic area & Forrest steppes \\
\hline $28 \leq \mathrm{IDM}<35$ & Wet & $30<\mathrm{IDM}<40$ & Periferic & Forrest \\
\hline $35 \leq \mathrm{IDM} \leq 55$ & Very wet & $\mathrm{IDM}>40$ & Abundantly & Forest \\
\hline IDM $>55$ & Extremely wet & & & \\
\hline
\end{tabular}

Source:Ducić and Anđelković, 2009; Gebremedhin, Kahsay, \& Fanta, 2018.

In order to calculate the annual drought index at selected meteorological stations, data about mean annual precipitation amounts $(\mathrm{P})$ and mean annual temperatures (T) for the defined period (2009-2018) were necessary. Number 10 is included to avoid negative index values, due to mean annual temperatures below $0^{\circ} \mathrm{C}$ that are typical for highland areas, assuming that the mean annual temperature will not be below $-10^{\circ} \mathrm{C}$ (Lungu, Panaitescu\& Plesoianu, 2012; Rajić and Zemunac, 2017). The annual drought index is calculated according to the pattern (Ducić and Anđelković, 2009): 


$$
I D M=\frac{\mathrm{P}}{(\mathrm{T}+10)}
$$

Seasonal index of drought is analyzed in order to detect the differentiation in the values of this climate index during the year. It is being calculated individually for each station for the period between 2009 and 2018. They are analyzed individually for each of the four seasons, by calculating the mean seasonal values of precipitation (Ps) and the mean seasonal values of temperature (Ts). For winter, the required data is taken for the December of last year, January and February. Spring season includes the data from March, April and May, summer season for June, July and August, while for the autumn season, the required data is from September, October and November. The seasonal drought index is calculated according to the following pattern (Gebremedhin, Kahsay, \& Fanta, 2018):

$$
I s D M=\frac{4 \mathrm{Ps}}{(T s+10)}
$$

The results of monthly drought index indicates the differentiation of this climate indicator during the both year and the season. Monthly values of De Marton's drought index indicates that these values has a significant influence on the climate characteristics of research area. The monthly drought index is calculated according to the following pattern (Milentijević et al., 2018):

$$
\operatorname{ImDM}=\frac{12 \mathrm{Pm}}{(\mathrm{Tm}+10)}
$$

\section{Research results}

Annual drought indices differ at meteorological stations in this part of Montenegro (Table 3). Highest value of the annual drought index has the meteorological station Plav (IDM=61,9), while the lowest value has Bijelo Polje (IDM=41,3). The values of the De Marton's index IDM $>55$ in Plav and Andrijevica, indicate extremely humid climate conditions in the period between 2009 and 2018. At other meteorological stations (Rožaje, Berane and Bijelo Polje), the values of the De Marton's index range from IDM=41,3-52,3 which indicates very humid climate conditions during the same period. The values of the De Marton's index are higher than IDM $>40$ at all meteorological 
Analysis of the spatial distribution of the drought in the Lim valley and on the upper course of the river Ibar in Montenegro

stations, which is an indicator of abundant drainage and coverage of the entire territory under forests.

While analyzing the value differences of De Marton's drought index, it can be noticed that it is decreasing through Lim valley. The amount of precipitation is also decreasing in that direction. Andrijevica receives most precipitation $(1113,83 \mathrm{~mm})$, while meteorological station at Bijelo Polje is station with the smallest amount of precipitation in the Lim valley $(876,9 \mathrm{~mm})$. The average annual temperature for the period between 2009 and 2018 is increasing down the Lim valley. Plav has the lowest average annual temperature $\left(9,8^{\circ} \mathrm{C}\right)$, while the meteorological station at Bijelo Polje shows biggest annual temperature $\left(11,2^{\circ} \mathrm{C}\right)$. Such distribution of these climate elements is affected by altitude, where increase of the altitude means that the average temperature decreases while the precipitation increases. This is directly reflected on changes on values of De Marton's drought index,which increase is proportional to the altitude and the sum of annual amount of precipitation, but inversely proportional to the average annual air temperature.

Table 3. Annual drought index

\begin{tabular}{|l|l|l|l|}
\hline $\begin{array}{l}\text { Meteorological } \\
\text { station }\end{array}$ & $\begin{array}{l}\text { Mean annual } \\
\text { temperature } \\
\left({ }^{\circ} \mathrm{C}\right)\end{array}$ & $\begin{array}{l}\text { Mean annual } \\
\text { precipitation } \\
(\mathrm{mm})\end{array}$ & $\begin{array}{l}\text { Annual drought } \\
(\mathrm{IDM})\end{array}$ \\
\hline Rožaje & $8,6^{\circ} \mathrm{C}$ & $972 \mathrm{~mm}$ & 52,3 \\
\hline Plav & $9,8^{\circ} \mathrm{C}$ & $1224,3 \mathrm{~mm}$ & 61,9 \\
\hline Andrijevica & $9,9^{\circ} \mathrm{C}$ & $1113,83 \mathrm{~mm}$ & 56 \\
\hline Berane & $10,7^{\circ} \mathrm{C}$ & $904,2 \mathrm{~mm}$ & 43,6 \\
\hline Bijelo Polje & $11,2^{\circ} \mathrm{C}$ & $876,9 \mathrm{~mm}$ & 41,3 \\
\hline
\end{tabular}

Source: Department of Hydrometeorology and Seismology of Montenegro, 2008-2018

The seasonal values of the De Marton's drought index differ at these meteorological stations depending on the season (Table 4). The highest values of this climate index are during the winter months due to low seasonal temperatures. The average value of the winter drought index is IsDM=117,8, which corresponds to the conditions of extremely humid climate. Plav has the highest average value of the winter drought index (IsDM=162,3), while Bijelo Polje has the lowest value (IsDM=77,9). The differences of the drought index during the winter between the places in the Lim valley are proportional to the differences in the annual values, so that the values decrease throughout the Lim valley. 
The spring and autumn values of the De Marton index are approximate. The average spring values are slightly higher compared to the autumn values at these meteorological stations. The values of the average spring index of IsDM=32,1 correspond to the conditions of a humid climate. Plav has by far the highest value of the spring drought index (IsDM=52,4), compared to other meteorological stations. Bijelo Polje has the lowest value of the spring drought index $(\mathrm{IsDM}=21,4)$ due to less precipitation and higher spring temperatures. The declining trend in the value of the De Marton drought index through the Lim valley is also present during the spring season. Rozaje has a lower value $(\mathrm{IsDM}=31,4)$ in relation to Plav and Andrijevica, but higher than Berane and Bijelo Polje.

Observing the average seasonal values of the De Marton drought index, it can be noticed that they are the lowest during the summer. The average value of the drought index during the summer months at these 5 meteorological stations is IsDM=11,2. It refers to the Mediterranean characteristics of the climate during the summer and according to that value it is close to the conditions of a moderately arid climate. The highest value of the summer drought index during the period 2009-2018 was recorded in Rožaje (IsDM=16,9), due to the higher amount of precipitation during the summer months compared to the other stations, which are covered by this research. Berane has the lowest value $(\mathrm{IsDM}=8,8)$ due to less precipitation during the summer months (June, July and August) compared to other meteorological stations.

Average values of the autumn drought index between the period of 2009 and 2018 are IsDM=27,3, which indicates moderately humid climates in that part of the year. Plav has the highest value of the autumn drought index (IsDM=33,1), while Bijelo Polje has the lowest value (IsDM=20,5). These values are decreasing through the Lim valley. Rozaje has lower values in relation to Plav and Andrijevica, but higher than Berane and Bijelo Polje.

Plav, Rožaje and Bijelo Polje have higher spring values compared to autumn, while the situation is reversed at the meteorological stations Andrijevica and Berane. Highest values of the winter, spring and autumn drought index were recorded at the meteorological station Plav, while the lowest in Bijelo Polje. During the summer season, there are deviations, so Rozaje has the highest value, and Berane has the lowest. The obtained results of seasonal drought index indicates that the differences between the examined meteorological stations are proportional to the differences in annual values during the winter, spring and autumn seasons. The exceptions are the ratios of these values during the summer season. 
Analysis of the spatial distribution of the drought in the Lim valley and on the upper course of the river Ibar in Montenegro

Table 4. Seasonal drought index

\begin{tabular}{|l|l|l|l|l|}
\hline \multirow{2}{*}{$\begin{array}{l}\text { Meteorological } \\
\text { station }\end{array}$} & \multicolumn{4}{|c|}{ Seasonal drought index (IsDM) } \\
\cline { 2 - 5 } & Winter & Spring & Summer & Autumn \\
\hline Rožaje & 115,7 & 31,4 & 16,9 & 26,7 \\
\hline Plav & 162,3 & 52,4 & 10,1 & 33,1 \\
\hline Andrijevica & 137,5 & 31,6 & 9,9 & 32 \\
\hline Berane & 95.7 & 23.8 & 8.8 & 24.3 \\
\hline Bijelo Polje & 77,9 & 21,4 & 10,1 & 20,5 \\
\hline Average & 117,8 & 32,1 & 11,2 & 27,3 \\
\hline
\end{tabular}

Source: Department of Hydrometeorology and Seismology of Montenegro, 2008-2018

Monthly drought indexes vary by months at the examined meteorological stations (Table 5). The highest average monthly values of the De Marton's drought index, for these 5 stations, were recorded for the winter months: January (ImDM=110,38), December $(\operatorname{ImDM}=103,18)$ and February $(\operatorname{ImDM}=93,22)$. Plav and Andrijevica have the highest values of monthly drought index during the winter months, whose index values exceed ImDM $>100$. Rožaje has the lowest values of the drought index for the months of December (ImDM=75,6) and February (ImDM=70,6), while Bijelo Polje has the lowest January values $(\operatorname{ImDM}=83,2)$. The monthly values for December and January decrease in proportion to the annual values down the Lim valley.

The values of the monthly indexes for the spring months are lower compared to the winter months, but higher compared to the months during the summer season. At the meteorological stations on the Lim Valley, the March values are lower than in February, but almost twice as high as in April. Rozaje is an exception with a higher index for March $(\operatorname{ImDM}=81,4)$ compared to February (ImDM=70,6). At all meteorological stations, there is an increase in the index during May compared to April. The highest values of monthly indexes for March (ImDM=104,3) and April $(\operatorname{ImDM}=53,4)$ were recorded in Plav, while Andrijevica has the highest monthly index for May (ImDM=61). In Bijelo Polje, the lowest monthly values of the De Marton's index for March $(\operatorname{ImDM}=55,3)$ and April $(\operatorname{ImDM}=32,8)$ were recorded, while Berane has the lowest May value $(\operatorname{ImDM}=44,8)$ of this climate indicator.

De Marton's values of drought index for summer months are significantly lower. June, compared to May, has lower values on all of the examined stations, while July values are higher than in August. August is a month that has least values of De Marton's index of drought throughout the 
year $(\operatorname{ImDM}=17,36)$. Rozaje has the highest values for each of the summer months. Berane has smallest values for June $(\operatorname{ImDM}=30,9)$ and August $(\operatorname{ImDM}=13,1)$, while lowest value at July was recorded at Andrijevica $(\operatorname{ImDM}=18,4)$.

Monthly values for autumn months are being increased as the season passes. Average values at these five stations are changing as follows: September values $(\operatorname{ImDM}=34,48)$ are higher than in August $(\operatorname{ImDM}=17,36)$, but lower compared to October $(\operatorname{ImDM}=57,74)$, while October's values are lower in relation to the November ones $(\operatorname{ImDM}=85,04)$. Meteorological station at Rozaje has biggest values for September $(\mathrm{ImDM}=40,4)$, while Plav has biggest values for October and November (ImDM=69,3; ImDM=110,3 - accordingly). Bijelo Polje has the lowest values of monthly indexes for all months during the autumn. The legality of the values of the monthly drought indices falling down the Lim valley is represented in all months during the autumn.

Table 5. Monthly drought indexes(ImDM)

\begin{tabular}{|l|r|r|r|r|r|r|}
\hline Month & Rožaje & Plav & Andrijevica & Berane & $\begin{array}{l}\text { Bijelo } \\
\text { Polje }\end{array}$ & $\begin{array}{l}\text { Average } \\
\text { (ImDM) }\end{array}$ \\
\hline I & 97,6 & \multicolumn{1}{|c|}{155,2} & 123,3 & 92,6 & 83,2 & 110,38 \\
\hline II & 70,6 & 132,5 & 112,3 & 72,1 & 78,6 & 93,22 \\
\hline III & 81,4 & 104,3 & 87,6 & 67,6 & 55,3 & 79,24 \\
\hline IV & 42,6 & 53,4 & 45,9 & 37,9 & 32,8 & 42,52 \\
\hline V & 59,4 & 60,2 & 61 & 44,8 & 45,4 & 54,16 \\
\hline VI & 54,7 & 31 & 36,6 & 30,9 & 31,4 & 36,92 \\
\hline VII & 34,1 & 23 & 18,4 & 18,9 & 25,4 & 23,96 \\
\hline VIII & 27,7 & 16,5 & 14,6 & 13,1 & 14,9 & 17,36 \\
\hline IX & 40,4 & 37,6 & 36,1 & 30,6 & 27,7 & 34,48 \\
\hline X & 53,6 & 69,3 & 66,2 & 54,6 & 45 & 57,74 \\
\hline XI & 69,4 & 110,3 & 106,9 & 75 & 63,6 & 85,04 \\
\hline XII & 75,6 & 147,1 & 118,8 & 90,8 & 83,6 & 103,18 \\
\hline
\end{tabular}

Source: Department of Hydrometeorology and Seismology of Montenegro, 2008-2018

In order to analyze variation of drought during the year in more detail, it is necessary to point out single months that has higher amount of drought, in which the value of De Marton's index is ImDM $<20$. Months that are characterized by drought are only present during the summer season, while, out of the all examined stations, only Rozaje doesn't have single dry month during this research period. August is the only dry month (except for the Rozaje), because all the values are lower than ImDM=20 on De Marton's drought index: Plav (ImDM=16,5), Bijelo Polje (ImDM=14,9), Andrijevica 
Analysis of the spatial distribution of the drought in

the Lim valley and on the upper course of the river Ibar in Montenegro

$(\operatorname{ImDM}=14,6)$ and Berane (ImDM=13,1). July, during this examined period, is a dry month on the following meteorological stations: Andrijevica $(\operatorname{ImDM}=18,4)$ and Berane $(\mathrm{ImDM}=18,9)$.

The dry months are ocurr due to the higher average temperature in the summer months. The difference in mean summer temperatures is present between Berane and Bijelo Polje with average summer temperatures above $20^{\circ} \mathrm{C}$, while average summer temperatures below $20^{\circ} \mathrm{C}$ can be found at Plav $\left(18,8^{\circ} \mathrm{C}\right)$ and Andrijevica $\left(19^{\circ} \mathrm{C}\right)$. At the meteorological station Rozaje, dry months are not present even during the summer due to a slightly lower average summer temperature $\left(17,6^{\circ} \mathrm{C}\right)$, which is a consequence of higher altitude.The amount and regime of precipitation during the summer is a significant factor of dry months. The amount of precipitation in the summer season is significantly lower compared to other seasons. The average amount of precipitation at all meteorological stations during this period of research is $62,3 \mathrm{~mm}$. The average amount of precipitation for all meteorological stations is $84,56 \mathrm{~mm}$ for June, $59,5 \mathrm{~mm}$ for July and $42,98 \mathrm{~mm}$ for August. Rožaje has the highest average amount of precipitation during the summer $(88,31 \mathrm{~mm})$ due to the higher altitude. At other meteorological stations, the average amount of precipitation during the summer ranges from $52-60 \mathrm{~mm}$.

\section{Conclusion}

Climate change exacerbates soil degradation processes, mainly through changes in precipitation and evapotranspiration regimes that are further exacerbated by the occurrence of extreme meteorological events (Soils, Society and Global Change, 2007). Understanding the climatic conditions of a particular area is an essential step for studying different human activities (Piri et al., 2017). Aridity is characterized by rare and highly variable precipitation that is usually associated with a high degree of evaporation (Rakhecha and Dhar, 1975). Drought analysis and quantification in a particular area is important for all those who are working in the field of climate change, environmental protection, improving the management strategy of agriculture and water management (Rajić and Zemunac, 2017; Zemunac, Rajic, \& Bezdan, 2018). One of the most dangerous and harmful effects of drought is the pressure on natural resources (water, land, air), habitats and ecosystems, and in addition it has an impact on numerous other processes and phenomenons (Maticić, 2002). 
Considering the importance of climatic features and modern changes on the transformation of the natural environment and the impact on economic activities, this research paper gives an overview of annual, seasonal and monthly values of drought index at meteorological stations Rozaje (Ibar valley), Plav, Andrijevica, Berane and Bijelo Polje (Lim valley). Annual drought index with IDM values greated than 40 indicates that the climate of this area is humid and that the aridization process in this area is still not represented. The annual values of the De Marton's drought index are proportional to the increase in altitude and the amount of precipitation, and inversely proportional to the annual temperature. The values of the annual drought index using the De Marton's model are IDM=61,9 for Plav, IDM=56 for Andrijevica, IDM=52,3 for Rožaje, IDM=43,6 for Berane and IDM=41,3 for Bijelo Polje.

Regardless of the high annual values of the drought index, based on the analysis of seasonal and monthly values of the drought index, oscillations of this parameter were established during the year. The highest seasonal values of the drought index are during the winter ( $\mathrm{IsDM}=117,8)$, while they are lowest during the summer (IsDM=11,2) on average for all analyzed meteorological stations. The months with the highest values of the drought index are January $(\operatorname{ImDM}=110,38)$ and December $(\operatorname{ImDM}=103,18)$. August is the month in which the average value of the drought index is $\operatorname{ImDM}=17,36$ and based on the individual values for each meteorological station, it is the dry month at all meteorological stations in the Lim valley.

\section{Acknowledgement}

The paper is the result of the research on the University of BelgradeFaculty of Geography, which is financed by the Ministry of Education, Science and Technological Development of the Republic of Serbia.

\section{References}

Ahmed, K., Shahid,S., Wang, X., Nawaz, N., \& Khan, N. (2019). Spatiotemporal changes in aridity of Pakistan during 1901-2016. Hydrology and Earth System Sciences, 23(7), 3081-3096.

Bakić, R. (2005). Gornje Polimlje. Nikšić: Filozofski fakultet Nikšić, Institut za geografiju. 
Analysis of the spatial distribution of the drought in the Lim valley and on the upper course of the river Ibar in Montenegro

Baltas, E. (2007). Spatial distribution of climatic indices in northern Greece. Meteorological Applications: A journal of forecasting, practical applications, training techniques and modelling, 14(1), 69-78.

Bačević, N., Vukoičić, D., Nikolić, M., Janc, N., Milentijević, N., \& Gavrilov, B. M. (2017). Aridity in Kosovo and Metohija, Serbia. Carpathian Journal of Earth and Environmental Sciences, 12(2), 563-570.

Cvijić, J. (1921). Ledeno doba u Prokletijama i okolnim planinama. Beograd: Glasnik SKA, XCIII.

Dabbaghi, M., Manjari, A. (2017). The Climate Survey of Razan-Qahavand Plain Through de-Martonne Aridity Index. The International Journal of Engineering and Science, 6 (9), 49-60.

Ducić, V., Anđelković, G. (2009). Klimatologija praktikum zageografe. Beograd: Univerzitet u Beogradu - Geografski fakultet.

Dukić, D. (1976). Klimatologija. Beograd: Geografski fakultet.

Dragićević, S., Filipović, D. (2009). Prirodni uslovi i nepogode u planiranju $i$ zaštiti prostora. Beograd: Univerzitet u Beogradu - Geografski fakultet.

Gavrilov, M. B., An, W., Xu, C., Radaković, M. G., Hao, Q., Yang, F., ... \& Marković, S. B. (2019). Independent Aridity and Drought Pieces of Evidence Based on Meteorological Data and Tree Ring Data in Southeast Banat, Vojvodina, Serbia. Atmosphere, 10(10), 586.

Gebremedhin, M. A., Kahsay, G. H., \& Fanta, H. G. (2018). Assessment of spatial distribution of aridity indices in Raya valley, northern Ethiopia. Applied Water Science, 8(8), 1-8.

Joksimović, M. M. (2017). Specifični oblici turizma u funkciji razvoja Gornjeg Polimlja (Doktorska disertacija, Univerzitet u Beogradu-Geografski fakultet).

Kosmas, C., Kirkby, M. \& N. Geeson (1999). Manual on: Key indicators of desertification and mapping environmentally sensitive areas to desertification. European Commission, Energy, Environment and Sustainable Development, EUR 18882, 87 p.

Lungu, M., Panaitescu, L., \& Plesoianu, D. (2012). Aridity, risk climatic phenomenon in Danube Delta. In Water resources and wetlands, editors: petre Gâş̧tescu, William Lewis Jr., petre Brețcan conference proceedings (pp. 14-16). 
Marani-Barzani, M., Eslamian, S., Amoushahi-Khouzani, M., Gandomkar, A., Rajaei-Rizi, F., Kazemi, M., ... \& Askari, Z. (2017). Assessment of Aridity Using Geographical Information System in Zayandeh-Roud Basin, Isfahan, Iran. International Journal of Mining Science, 3(2), 49-61.

Marković, J. (1966). Geografske oblasti Socijalističke Federatione Republike Jugoslavije. Beograd: Zavod za izdavanje udžbenika SR Srbije.

Maticić, B. (2002). International Conference on Drought Mitigation and Prevention of Land Desertification. Bled, Slovenia, April 2002.

MONSTAT - Uprava za statistiku Crne Gore. (2011). Popis stanovništva, domaćinstava i stanova u 2011.godini. Podgorica: Uprava za statistiku.

Milentijević, N., Dragojlović, J., Ristić, D., Cimbaljević, M., Demirović, D., \& Valjarević, A. (2018). The assessment of aridity in Leskovac Basin, Serbia (1981-2010). Journal of the Geographical Institute" Jovan Cvijic", SASA, 68(2), 249-264.

Ministarstvo poljoprivrede i ruralnog razvoja Crne Gore. (2020). Strateška procjena utucaja na životnu sredinu plana razvoja šuma za šumsko područje Rožaje 2020. - 2029. Podgorica: Ministarstvo poljoprivrede i ruralnog razvoja.

Paltineanu, C., Tanasescu, N.,Chitu,E., \& Mihailescu,I.F. (2007). Relationships between the De Martonne aridity index and water requirements of some representative crops: A case study from Romania. International agrophysics, 21(1).

Pellicone, G., Caloiero, T., \& Guagliardi, I. (2019). The De Martonne aridity index in Calabria (Southern Italy). Journal of Maps, 15(2), 788-796.

Piri, I., Khanamani, A., Shojaei, S., \& Fathizad, H. (2017). Determination of the best geostatistical method for climatic zoning in Iran. Applied Ecology and Environmental Research, 15(1), 93-103.

Popović, T., Radulović, E., \& Jovanović, M. (2020). Koliko nam se menja klima, kakva će biti naša buduća klima? Beograd: Ministarstvo nauke i zaštite životne sredine, Agencija za zaštitu životne sredine.

Radojičić, B. (2015). Crna Gora - Geografski enciklopedijski leksikon. Nikšić: Filozofski fakultet Nikšić.

Radojičić, B. (2005). Vode Crne Gore. Nikšić: Filozofski fakultet Nikšić, Institut za geografiju, posebno izdanje. 
Analysis of the spatial distribution of the drought in the Lim valley and on the upper course of the river Ibar in Montenegro

Radojičić, B. (2002). Geografija Crne Gore - Društvena osnova. Podgorica: DANU.

Rajić, M. (2014). Analiza trajnih sušnih perioda na području Severnog Banata. Letopis naučnih radova poljoprivrednog fakulteta, 38(1), 117-124.

Rajić, M., \& Zemunac, R. (2017). Poređenje različitih metoda za ocenu suše na području Južne Bačke. Letopis naučnih radova poljoprivrednog fakulteta, $42(1), 68-76$.

Rakhecha, P. \& O.N. Dhar (1975). A study of aridity and its fluctuations over Andhra Pradesh. Indian institute of tropical meteorology,Poona-5. Vol. 42, A, No.2.

Rakićević, T. (1971). Opšta fizička geografija. Beograd: Zavod za izdavanje udžbenika Socijalističke Republike Srbije.

Spinoni, J., Naumann, G., \& Vogt, J. V. (2017). Pan-European seasonal trends and recent changes of drought frequency and severity. Global and Planetary Change, 148, 113-130.

Soils, Society \& Global Change. Celebrating the Centenary of Conservation and Restoration of Soil Vegetation in Iceland. 31 August - 4 September 2007, Selfoss, Iceland.

Tadić, L., Dadić, T., \& Bosak, M. (2015). Usporedba različitih metoda za ocjenu suše na području kontinentalne Hrvatske. Građevinar, 67(01.), 1122.

Todić, D. (2016). Pariski sporazum o klimi u svetlu ciljeva i principa savremene politike i prava životne sredine. Institut za međunarodnu politiku i privredu (vol. 13, br. 3, str. 45-62). Beograd: Megatrend revija.

Zavod za hidrometeorologiju i seizmologiju Crne Gore (2018). Godišnjak meteoroloških $i$ hidrometeoroloških podataka.Podgorica: Zavod za hidrometeorologiju i seizmologiju Crne Gore.

Zemunac, R., Rajic, M., \& Bezdan, A. (2018). Analiza metoda za kvantifikaciju suše. XXIII Savetovanje u biotehnologiji, Zbornik radova, 396-401.

Vujević, P. (1948). Meteorologija. Beograd: Izdavačko preduzeće Srbije Prosveta. 